\title{
Effect of soy oil, orange (Citrus sinensis) peel oil and their blends on total phospholipid, lipid peroxidation, and antioxidant defense system in brain tissues of normo rats
}

\author{
O.L. Erukainure ${ }^{\mathrm{a} \bowtie}$, J.A. Ajiboye ${ }^{\mathrm{b}}$, F.F. Davis ${ }^{\mathrm{b}}$, K. Obabire ${ }^{\mathrm{b}}$, E.E. Okoro ${ }^{\mathrm{c}}$, \\ S.O. Adenekan ${ }^{\mathrm{d}}$, M.V. Adegbola ${ }^{\mathrm{e}}$, B.J. Awogbemi ${ }^{\mathrm{f}}$, B.O. Odjobo ${ }^{\mathrm{f}}$ and M.Z. Zaruwa ${ }^{\mathrm{g}}$ \\ a Department of Food Technology, Federal Institute of Industrial Research, Oshodi, Nigeria \\ ${ }^{\mathrm{b}}$ Biochemistry Department, Bells University of Technology, Ota, Nigeria \\ ${ }^{\mathrm{c}}$ College of Health and Sciences, Adventist University of West Africa, Monrovia, Liberia \\ ${ }^{\mathrm{d}}$ Department of Biochemistry, University of Lagos, Lagos, Nigeria \\ e Department of Laboratory Technology, Federal Polytechnic, Ede, Nigeria \\ Analytical Division, Federal Institute of Industrial Research, Oshodi, Nigeria \\ ${ }_{\mathrm{g}}^{\mathrm{g}}$ Faculty of Science, Adamawa State University, Mubi, Nigeria \\ Corresponding Author: loreks@yahoo.co.uk
}

Submitted: 18 March 2015; Accepted: 06 July 2015

SUMMARY: Soy and orange peel (C. sinensis) oils were fed to albino male rats to determine their effects on malondialdehyde (MDA), total phospholipid (TP) content and oxidative stress biomarkers of brain tissue. Beside mouse chow, four diets were designed to contain $50 \%$ of their energy as carbohydrate, $35 \%$ as fat, and $15 \%$ as protein, and one lipid-free diet which had distilled water substituted for fat. Groups of five rats were each fed one of these diets, while a fifth group was fed pelletized mouse chow. A significant difference $(\mathrm{p}<0.05)$ was observed in the TP of the mouse chow group. The TP was highest $(\mathrm{p}<0.05)$ in those fed the soy and orange peel oil blend as compared to those fed these oils separately. Feeding soy oil led to decreased MDA in brain tissues and influenced the TP content. Significantly lower $(\mathrm{p}<0.05)$ GSH and SOD activities were observed in the groups fed soy oil+orange peel oil, and soy oil diets respectively. Higher significant $(p<0.05)$ activities were observed in the orange oil fed group. Significantly higher $(\mathrm{p}<0.05)$ catalase activity was observed in the lipid free diet fed group, which was followed by orange peel oil, and soy oil+orange peel oil diets, respectively. A combination of both oils may be useful in the management of certain neurological diseases or illnesses and protect against other oxidative stress complications.

KEYWORDS: Brain; Dietary fatty acids; Lipid peroxidation (LPO); Malondialdehyde (MDA); Phospholipids

RESUMEN: Efecto de los aceite de soja y de cáscara de naranja (Citrus sinensis) y sus mezclas sobre fosfolípidos totales, peroxidación lipídica y el sistema de defensa antioxidante, en tejidos cerebrales de normo ratas. Ratas albinas machos fueron alimentadas con aceites de soja y de cáscara de naranja (C. sinensis) para determinar su efecto sobre el malondialdehído (MDA), fosfolípidos (TP) y el contenido total de biomarcadores del estrés oxidativo de su tejido cerebral. Además de alimento para ratones, cuatro dietas fueron diseñadas conteniendo el $50 \%$ de la energía en forma de carbohidratos, el 35\% en forma de grasa, y el 15\% como proteína, y una cuarta dieta libre de lípidos donde se había sustituido la grasa por agua destilada. Grupos de cinco ratas fueron alimentadas cada uno con estas dietas, mientras que un quinto grupo fue alimentado con alimento para ratones peletizado. Se observó una diferencia significativa $(\mathrm{p}<0,05)$ en TP del grupo alimentado concomida para ratón. Los TP fue mayor $(\mathrm{p}<0,05)$ en los alimentados con mezcla de aceite de soja y de cáscaras de naranja, en comparación 
con los alimentados con estos aceites por separado. La alimentación con aceite de soja llevó a una disminución del MDA en los tejidos del cerebro e influyó en el contenido de TP. Se observó un descenso significativo $(\mathrm{p}<0,05)$ de las actividades de GSH y SOD en los grupos alimentados con aceite de soja+aceite de piel de naranja, y con las dietas de aceite de soja. Se observaron actividades significativamente más altas $(\mathrm{p}<0,05)$ en el grupo alimentado con aceite de naranja. Una actividad catalasa significativamente mas alta $(p<0,05)$ se observó en el grupo alimentado con una dieta libre de lípidos, seguido por grupo alimentado con aceite de la cáscara de naranja y el que incluía en su dieta la mezcla aceite de soja+cáscara de naranja respectivamente. La combinación de ambos aceites puede ser útil en el control de ciertas enfermedades neurológicas y en la protección contra las complicaciones del estrés oxidativo.

PALABRAS CLAVE: Ácidos grasos de la dieta; Cerebro; Fosfolípidos; Malondialdehído (MDA); Peroxidación lipídica $(L P O)$

Citation/Cómo citar este artículo: Erukainure OL, Ajiboye JA, Davis FF, Obabire K, Okoro EE, Adenekan SO, Adegbola MV, Awogbemi BJ, Odjobo BO, Zaruwa MZ. 2016. Effect of soy oil, orange (Citrus sinensis) peel oil and their blends on total phospholipid, lipid peroxidation, and antioxidant defense system in brain tissues of normo rats. Grasas Aceites 67 (1): e113. doi: http://dx.doi.org/10.3989/gya.0373151.

Copyright: (C) 2016 CSIC. This is an open-access article distributed under the terms of the Creative Commons Attribution-Non Commercial (by-nc) Spain 3.0 Licence.

\section{INTRODUCTION}

Oxidative stress has been reported to play a major role in the complication of most diseases and aging processing. It results from an excessive production of reactive oxygen species (ROS) which exceeds the cell's capacity to detoxify them, thereby leading to a significant decrease in the effectiveness of antioxidant defenses (Schafer and Buettner, 2001). Brain tissue is more susceptible to oxidative damage than other tissues owing to its fatty acid composition which may undergo peroxidation (Adibhatla and Hatcher, 2007; Foloyd et al., 2001).

Phospholipids are important components of all mammalian cells and are involved in signal transduction, cell structural integrity and storage (Adibhatla and Hatcher, 2007). The amount and fatty acid composition of various phospholipids varies among the different cellular membranes (Macdonald et al., 1996). Lipid metabolism is of particular importance for the CNS (Adibhatla and Hatcher, 2007), where the concentration of lipids is high. Brain membrane phospholipids are rich in polyunsaturated fatty acids (PUFAs), especially the (n-3) series (Bourre et al., 1992), which are important for maintaining membrane fluidity. Although the gross composition of brain lipids is less readily modified by dietary factors than in other body organs (Bourre et al., 1993), recent evidence suggests that prolonged ingestion of defined dietary fats may lead to alterations in specific fatty acids in brain membranes and membrane enzymes (Murray et al., 2003).

Soybean [Glycine max (L.) Merrill] has been extensively used as an important source of dietary protein and oil (Dixit et al., 2011). Soybean oil has been documented to be a rich source of Omega 3 and Omega 6 (Karasulu et al., 2011). It is a rich source of vitamin $\mathrm{E}$ which aids the body in scavenging free radicals thus protecting against oxidative stress $(\mathrm{Lu}$ and Liu, 2002). Its high Vitamin B content aids in digestion thus preventing chronic digestion problems and constipation (Kummerow et al., 2007).

The orange peel is an excellent natural protective coating for that fruit and provides resistance against UV light, fungi, insects, and mechanical abrasion (Min-Hsiung, 2009). Flavonoids, consisting mainly of polymethoxylated flavonoids, terpenoids, such as limonene and linalool, and other volatile oils are the major ingredients of orange peel. Polymethoxylated flavonoids exist almost exclusively in citrus genus, particularly in the peel of sweet orange (C. sinensis) and mandarin (Citrus reticulata Blanco) (Min-Hsiung, 2009). Medicinally, orange peel has been used in traditional medicine in some Asian and African countries for relieving stomach upset, skin inflammation, muscle pain, and ringworm infections (Bejar et al., 2001).

This study aims to report the effect of feeding soy and/or orange ( $C$. sinensis) peel oil to albino male rats on oxidative stress biomarkers and the total phospholipid content of their brain tissues.

\section{MATERIALS AND METHODS}

\subsection{Plant materials}

About $5000 \mathrm{~g}$ of fully ripened local sweet oranges were purchased from an Ikorodu market, Lagos, Nigeria, and were peeled manually. The blended sample was subjected to hydro-distillation for $3 \mathrm{~h}$ using a Clevenger type apparatus. The oil obtained was dried over sodium sulphate over night, filtered, and then stored at $-2{ }^{\circ} \mathrm{C}$ until further analysis.

\subsection{GC-MS instrumentation}

GC: Agilent $6890 \mathrm{~N}$ gas chromatograph, FID at $280{ }^{\circ} \mathrm{C}, \mathrm{N}_{2}$ at $1.0 \mathrm{~mL} \cdot \mathrm{min}^{-1}, \mathrm{ZB}-5 \mathrm{HT}$ capillary column ( $30 \mathrm{~m} \times 0.53 \mathrm{~mm}$ ID; $0.32 \mathrm{~mm}$ ), split ratio $1: 30$ injector temperature of column $260{ }^{\circ} \mathrm{C}$, temperature 
of column maintained at $70^{\circ} \mathrm{C}$ for three minutes and then raised to $235^{\circ} \mathrm{C}\left(5{ }^{\circ} \mathrm{C} \cdot \mathrm{min}^{-1}\right)$ followed by five minutes at $260^{\circ} \mathrm{C}$.

GC-MS: Hewlett Packard 6890 gas chromatograph combined with a Jeol JMS-HX 110 mass spectrometer with source at $270{ }^{\circ} \mathrm{C}$ at $70 \mathrm{eV}$. The injector was set at $270{ }^{\circ} \mathrm{C}$ with a split ratio of 1:30. A mass spectral survey was performed using the NIST mass spectral program 2008. The concentrations of the identified compounds were calculated using area normalization over the FID response method.

\subsection{Preparation of experimental diets}

Four diets were prepared using the formula described by Howell et al. (1998) and designed to contain $50 \%$ of energy as carbohydrate, $35 \%$ as fat, and $15 \%$ as protein. A lipid-free diet had distilled water substituted for the fat. The protein requirement was provided as de-fatted soybean $(15 \%)$. Table 1 shows the composition of these diets.

\subsection{Feeding trials}

Twenty-five male albino rats, each weighing between 90-120 g were maintained in accordance with and with the approval of the Animal Ethical Committee, Bells University of Technology, Ota, Nigeria. They were acclimatized for one week on pelletized mouse chow (Ladokee ${ }^{\mathbb{B}}$ Feeds Nigeria Ltd., Nigeria) with water provided ad libitum at room temperature and a 12-hour light and dark cycle. They were randomly assigned into groups of five animals as shown below:

Group 1: Each group receiving pelletized mouse chow Group 2: Lipid-free diet (Diet 1)

Group 3: Orange peel oil diet (Diet 2)

Group 4: Soy oil diet (Diet 3)

Group 5: Soy oil+orange peel oil diet, respectively (Diet 4)

The rats were monitored daily for food and water intake, and body weight. At the end of the sixth week, the rats were fasted overnight and sacrificed by cervical dislocation. Brain tissues were collected after dissection of the skull and stored at $\leq 2{ }^{\circ} \mathrm{C}$ until further analysis.

TABLE 1. Composition of experimental diets

\begin{tabular}{lcccc}
\hline Ingredients & Diet 1 & Diet 2 & Diet 3 & Diet 4 \\
\hline Corn starch & $50 \%$ & $50 \%$ & $50 \%$ & $50 \%$ \\
$\begin{array}{l}\text { Soybean powder } \\
\quad \text { defatted) }\end{array}$ & $15 \%$ & $15 \%$ & $15 \%$ & $15 \%$ \\
Orange peel oil & - & $35 \%$ & - & $17.5 \%$ \\
Soy oil & - & - & $35 \%$ & $17.5 \%$ \\
Distilled water & $35 \%$ & - & - & - \\
\hline
\end{tabular}

\subsection{Parameter assays}

Total lipids were extracted from each brain with chloroform/methanol (2:1, v/v) as described in (Folch et al., 1957) after homogenization of $3 \mathrm{~g}$ of tissue in a mixer. Non-lipid contaminants were then extracted into a $0.88 \% \mathrm{KCl}$ solution. The extracted lipids were then evaporated on a rotary evaporator, and stored at $-2{ }^{\circ} \mathrm{C}$. Total Phospholipid content was determined according to the method described by Bartlett (1959).

Lipid peroxidation was determined by measuring malondialdehyde (MDA) formed by the thiobarbituric acid reaction (TBAR) (Chowdhury and Soulsby, 2002). Catalase (CAT) activity was estimated by measuring the rate of decomposition of $\mathrm{H}_{2} \mathrm{O}_{2}$ (Aebi, 1983). The level of superoxide dismutase (SOD) activity was determined by the method of Misra and Fridovich (1972); while the method of Ellman (1959) was adopted for estimating the activity of reduced glutathione (GSH).

\subsection{Statistical Analysis}

To address the biological variability, each set of experiments was repeated at least three times. Differences among the groups were analyzed by oneway analysis of variance (ANOVA) with the aid of SPSS software (SPSS Inc., Chicago, IL, USA) standard version 17 . The $p$ values of $<0.05$ were considered statistically significant for differences in means using the least significant difference. Data were reported as mean \pm standard deviation. The correlation between total phospholipids and malondialdehyde was analyzed using Microsof ${ }^{\mathbb{B}}$ Excel 2007.

\section{RESULTS}

No significant difference was observed in the food or water intake of the rats in all groups throughout the study period. Body weight gains did not differ significantly among groups (data not shown).

GCMS characterization of the orange peel oil revealed the presence of terpenes and its derivatives, with $\mathrm{D}$-Limonene being the most prominent compound $(96.70 \%)$ present as depicted in Table 2.

Significantly lower $(\mathrm{p}<0.05)$ GSH and SOD activities were observed in groups fed soy oil+orange peel oil, and soy oil diets, respectively, as depicted in Figure 1. Higher significant $(\mathrm{p}<0.05)$ activities were observed in the orange oil fed group. No significant difference was observed in the lipid-free diet as compared to the normal pelletized chows. Significantly higher $(\mathrm{p}<0.05)$ catalase activity was observed in the lipid-free diet fed group. This was followed by orange peel oil, and soy oil+orange peel oil diets, respectively. The lowest activity was observed in the soy oil fed group.

The results for MDA content are presented in Figure 2. Significantly higher levels $(p<0.05)$ were 
TABLE 2. Identified compounds in orange peel oil

\begin{tabular}{lcrl}
\hline Peak No. & $\begin{array}{c}\text { Retention } \\
\text { time (min) }\end{array}$ & Area $\%$ & \multicolumn{1}{c}{ Compound } \\
\hline 1 & 4.17 & 0.01 & Pregnane-11,20-dione \\
2 & 4.29 & 0.07 & Xylene \\
4 & 5.33 & 0.38 & $\alpha$-Pinene \\
6 & 6.04 & 0.28 & ß-Phellandrene \\
7 & 6.34 & 1.52 & Pyridine, 2-methyl- \\
9 & 6.70 & 0.14 & 4-Carene, (1S, 3S, 6R)-(-)- \\
10 & 7.29 & 96.70 & D-Limonene \\
13 & 8.43 & 0.22 & 2-Hexyn-1-ol \\
\hline
\end{tabular}

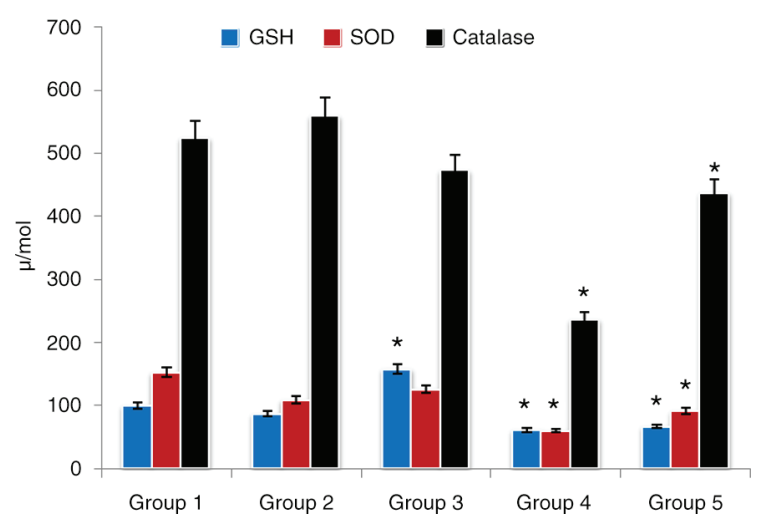

FIGURE 1. Activities of antioxidant defense enzymes in the brains of experimental groups. Values $=$ mean $+S D ; n=5$. *Statistically significant $(\mathrm{p}<0.05)$ as compared to group 1 .

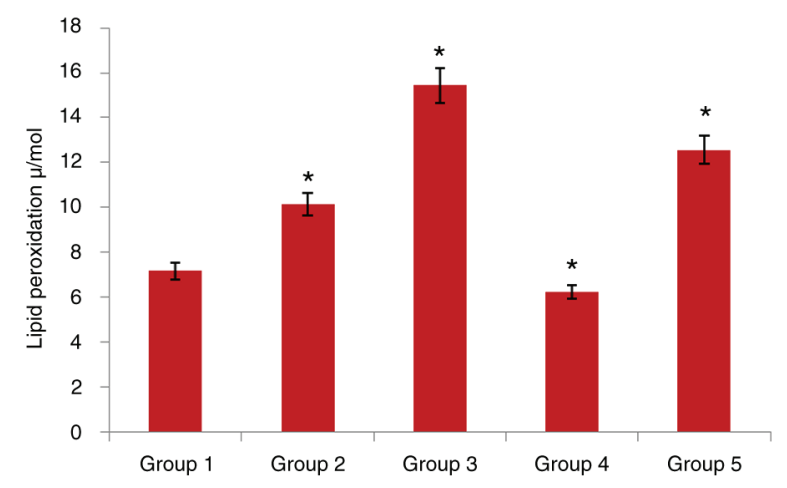

FIGURE 2. Malondialdehyde (MDA) content in brain tissues of experimental groups. Values $=$ mean $+\mathrm{SD} ; \mathrm{n}=5$. *Statistically significant $(\mathrm{p}<0.05)$ as compared to group 1.

observed in the groups fed orange peel oil, and soy oil+orange peel oil diets, respectively, than in those fed the other diets. The lowest level was observed in the group fed the soy oil diet.

The results for TP content are presented in Figure 3. Significant differences $(p<0.05)$ were observed in the

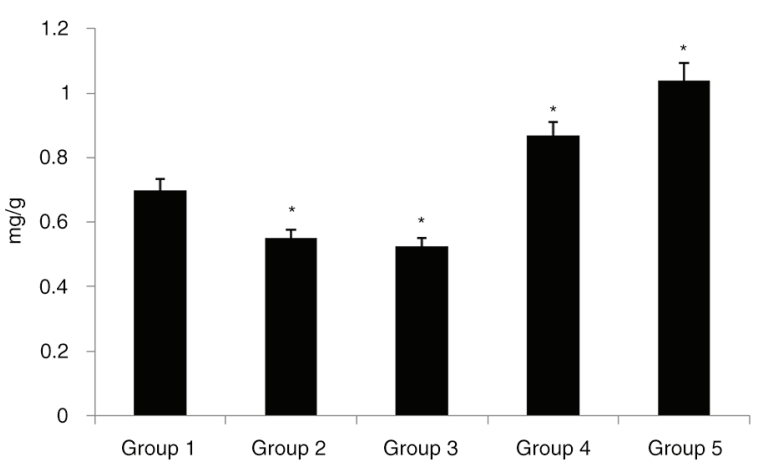

FIGURE 3. Total phospholipid (TP) contents in brain tissues of experimental groups. Values $=$ mean $+\mathrm{SD} ; \mathrm{n}=5$. *Statistically significant $(\mathrm{p}<0.05)$ as compared to group 1.

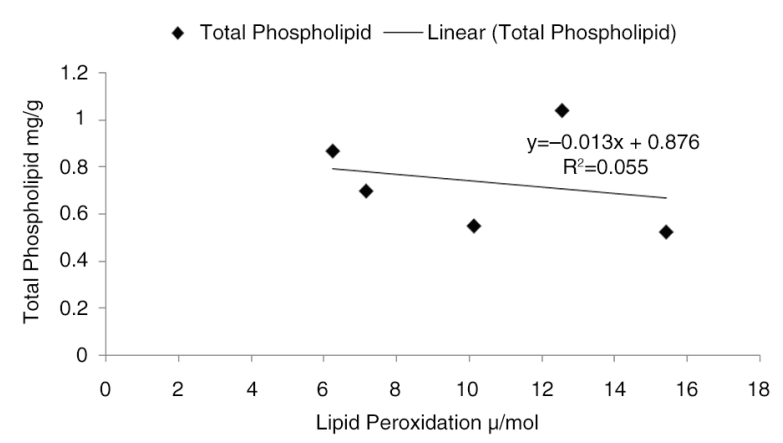

FIGURE 4. Correlation between total phospholipids and Malondialdehyde (MDA) in brain tissues of experimental groups.

TP of the groups fed pelletized mouse chow and lipidfree diet, respectively. The TP in the group fed the soy oil+orange peel oil diet was significantly higher than in the groups fed the soy oil diet.

A positive correlation $(\mathrm{R}=0.055)$ was observed between TP and lipid peroxidation as shown in Figure 4. The TP content was observed to reduce with increasing lipid peroxidation.

\section{DISCUSSION}

The chemistry and function of developing and of mature brains can be influenced by diet (Murray et al., 2003; Fernstrom, 2000; Dyer and Grennwood, 1991). Soy oil contains significant quantities of n-3 fatty acids (Lovell, 1994), and may be responsible for the high TP content in rats fed the soy oil diet. The long-chain n-3 PUFAs are major structural components of the membrane phospholipids of tissues throughout the body and in addition, they influence membrane fluidity and ion transports (Lee and Lip, 2003). Orange peel oil has been reported to be high in terpenic aldehydes as indicated in Table 2 (Qiao et al., 2008). These aldehydes are most likely enzymatic degradation products of 
unsaturated fatty acids such as oleic acid, linoleic acid and linolenic acid (Lin and Rouseff, 2001), which makes orange peel oil low in n-3 PUFA. Our results indicate that the blend of soy and orange peel oils produced a significantly higher increase in the PL content of rat brains within six weeks than mouse chow and soy oil provided separately. Pandya et al. (2004) reported that the reduction in PL content is accompanied by major changes in composition, which is consistent with the membrane hypothesis of Alzheimer Disease (Roth et al., 1995), which states that in order to make up for choline deficiency, neurons try to extract choline from choline-containing phospholipids. This results in the disruption of cell membranes and ultimately in neuronal cell death (Wurtman, 1985). Dietary fatty acids (especially docosahexaenoic acid [22:6(n-3)] (DHA)) play a major role in the chemistry and function of both developing and mature brain contents of the mammalian brain (Innis, 2005). (+)- and (-)-trans-carveol, and (+)- and (-)-perillyl alcohol have been reported as the principle metabolites of limonene (Miyazawa et al., 2002). The enantiomers of perillyl alcohol are being viewed as novel therapeutic alternatives in some CNS neoplasms and other solid tumours, particularly for the treatment of gliomas (Fonseca et al., 2011). Therefore, the observed increase in the phospholipid content from feeding soy and orange peel oils together $(17.5 \%$ each) may be attributed to their ability to meet the essential fatty acid requirements and the therapeutic properties of limonene. The low TP content of the rats fed the lipid-free diet could be attributed to the absence of fatty acids.

The observed low GSH, SOD and catalase activities in the brain tissues of rats fed soy oil, and the blend of soy and orange peel oils indicate an occurrence of oxidative stress. The high activity observed in the orange peel oil fed group may be attributed to the antioxidant properties of $\mathrm{d}$-limonene. The antioxidant protective properties of $\mathrm{d}$-limonene have been reported in several studies. Murali et al. (2013) reported the protective potentials of d-lim onene against diabetic - induced oxidativestress. The anti-inflammatory and antioxidant properties of d-limonene were also reported by Murthy et al. (2013), thus, corresponding to our results (Figure 2).

Lipid peroxidation (LPO) is a marker of oxidative stress (Onyema et al., 2005). It can induce changes in fluidity and permeability, inhibit metabolic processes, and alter ion transport (Nigam and Schewe, 2000). Oxygen radicals oxidize the double bonds of unsaturated fatty acids of membrane PL. We found orange peel oil to significantly increase brain MDA content, suggesting that it induced a cellular stress response (Figure 2). Our rats fed soy oil had decreased brain MDA content. A possible role for soy protein as a dietary antioxidant in decreasing lipid peroxidation in rat brain has been reported
(Chowdhury and Soulsby, 2002). The isoflavones (e.g. genistein and diadzein) of soybeans have been reported to have antioxidant activity (Arora et al., 1998). Guliaeva et al. (1988) further reported that increased lipid peroxidation leads to a decrease in the PL content in rat brains. This agrees with the results that we obtained. However, this statement contradicts our observation when we fed a combined diet of soy and orange peel oils to rats. There was an increase in TP and MDA compared to the rats fed orange and soy oil, respectively. The increased MDA may be due to the high terpenic aldehydes of the orange peel oil (Qiao et al., 2008). Aldehydes have been shown to produce toxic compounds such as free radicals, peroxides and malonaldehyde by the oxidation of unsaturated fatty acids (Eckl et al., 1993). This implies that the observed overall effect of feeding the combined oil diet is not due to the reduced concentration of the respective oils. The low lipid peroxidation we observed in the brain tissues of rats fed lipid-free diets can be attributed to the absence of fatty acids.

\section{CONCLUSIONS}

Soy oil consumption led to decreased MDA and increased total phospholipid contents in rat brains compared to groups fed on pelletized mouse chows and a lipid-free diet. The consumption of orange peel and soy oil combinations further increased the total phospholipid content. This combination may be useful for the management of certain neurological ailments and protect against other oxidative stress complications. However, the observed increased MDA should be taken into consideration. Further studies are needed to evaluate the modulation of the fatty acid profiles of the phospholipids by these oils.

\section{REFERENCES}

Adibhatla RM, Hatcher JF. 2007. Role of lipids in brain injury and diseases. Future Lipidol. 2, 403-422. http://dx.doi.org/ 10.2217/17460875.2.4.403

Aebi HE. 1983. Methods in Enzymatic Analysis. Academic press, New York.

Arora A, Nair MG, Strasburg GM. 1998. Antioxidant activities of isoflavones and their biological metabolites in a liposomal system. Arch. Biochem. Biophys. 356, 133-141. http:// dx.doi.org/10.1006/abbi.1998.0783.

Bartlett GR. 1959. Phosphorus assay in column chromatography. J. Biol. Chem. 234, 466-468.

Bejar E, Bussmann R, Roa C, Sharon D. 2001. Herbs of Southern Ecuador: A Field Guide to the Medicinal Plants of Vilcabamba. Spring Valley, CA: LH Press.

Bourre JM, Bonneil M, Clement M, Dumont O, Durand G, Lafont H, Nalbone G, Piciotti M. 1993. Function of dietary polyunsaturated fatty acids in the nervous system. PLEFA. 48, 5-15. http://dx.doi.org/10.1016/0952-3278(93) 90003-F.

Bourre JM, Dumont OS, Piciotti MJ, Pascal GA, Durand GA. 1992. Dietary alpha-linolenic acid deficiency in adult rats for 7 months does not alter brain docosahexaenoic acid content, in contrast to liver, heart and testes. Biochim. Biophys. Acta 1124, 119-122. http://dx.doi.org/10.1016/ 0005-2760(92)90087-C. 
Chowdhury P, Soulsby M. 2002. Lipid peroxidation in rat brain is increased by simulated weightlessness and decreased by a soy-protein diet. Ann. Clin. Lab. Sci. 32, 188-192.

da Fonseca CO, Simão M, Lins IR, Caetano RO, Futuro D, Quirico-Santos T. 2011. Efficacy of monoterpene perillyl alcohol upon survival rate of patients with recurrent glioblastoma J. Cancer Res. Clin. Oncol. 137, 287-93. http://dx.doi.org/10.1007/s00432-010-0873-0.

Dixit AK, Antony JIX, Sharma NK, Tiwari RK. 2011. Soybean constituents and their functional benefits. In: Opportunity, Challenge and Scope of Natural Products in Medicinal Chemistry. Research Signpost, India.

Dyer JR, Grennwood CE. 1991. Dietary essential fatty acids change the fatty acid profile of rat neural mitochondria over time. J. Nutr. 121, 1548-1553.

Eckl PM, Ortner A, Esterbauer H. 1993. Genotoxic properties of 4-hydroxyalkenals and analogous aldehydes. Mutat Res. 290, 183-192. http://dx.doi.org/10.1016/0027-5107(93) 90158-C.

Ellman G. 1959. Tissue sulphydryl groups. Arch. Biochem. Biophy. 32, 70-77.http://dx.doi.org/10.1016/0003-9861(59)90090-6.

Fernstrom J. 2000. Can nutrient supplements modify brain function? Am. J. Clin. Nutr. 71, Suppl: 1669S-1673S.

Folch J, Lees M, Sladane-Stanley GHA. 1957. Simple method for the isolation and purification of total lipids from animal tissues. J. Biol. Chem. 226, 497-509.

Foloyd RA, West M, Hensley K. 2001. Oxidative biochemical markers; clues to understanding aging in long lived species. Exp. Gerontol. 36, 619-640. http://dx.doi.org/10.1016/S05315565(00)00231-X.

Guliaeva NV, Luzina NL, Levshina IP, Kryzhanovski GN. 1988. The inhibition stage of lipid peroxidation during stress. Bull. Eksp. Biol. Med. 106, 660-603.

Howell TJ, MacDougall DE, Jones PJH. 1998. Phytosterols partially explain differences in cholesterol metabolism caused by corn or olive oil feeding. J. Lipid Res. 39, 892-900.

Innis SM. 2005. Essential fatty acid metabolism during early development. In: Biology of Metabolism in Growing Animals. D.G. Burrin (Ed.) Pub. Elsevier Science, B.V. Amsterdam: Part III, pp. 235-274. http://dx.doi.org/10.1016/S18771823(09)70017-7.

Karasulu HY, Karasulu E, Büyükhelvacıgil M, Yıldız M, et al. 2011. Soybean oil: production process, benefits and uses in pharmaceutical dosage form. In: Soybean and health; El-Shemy H (Ed). InTech.

Kummerow FA, Mahfouz MM, Zhou Q. 2007. Trans fatty acids in partially hydrogenated soybean oil inhibit prostacyclin release by endothelial cells in presence of high level of linoleic acid. Prostaglandins Other Lipid Mediat. 84, 138-153. http://dx.doi.org/10.1016/j.prostaglandins.2007.07.001.

Lee KW, Lip GYH. 2003. The role of omega-3 fatty acids in the secondary prevention of cardiovascular disease. $Q \mathrm{~J}$. Med. 96, 465-480. http://dx.doi.org/10.1093/qjmed/hcg092.

Lin JM, Rouseff RL. 2001. Characterization of aroma-impact compounds in cold-pressed grapefruit oil using time-intensity
GC-olfactometry and GC-MS. Flavour Fragr. J. 16, 457-463. http://dx.doi.org/10.1002/ffj.1041.

Lovell RT. 1994. Nutrition and Feeding of Fish. An AVI Book Published by Van Nostrand Reinhold - New York, pp 61-62.

Lu C, Liu Y. 2002. Interaction of lipoic acid radical cations with vitamins $\mathrm{C}$ and $\mathrm{E}$ analogue and hydroxycinnamic acid derivatives. Arch. Bioc. Biophy. 406, 78-84. http://dx.doi.org/ 10.1016/S0003-9861(02)00411-3.

Macdonald RS, Zhang W, Zhang J, Surf GY. 1996. Brain neutral lipids and phospholipids are modified by long-term feeding of beef tallow vs. corn oil diets. J. Nutr. 126, 1554-1562.

Min-Hsiung P. 2009. Chemopreventive effects of natural dietary compounds on cancer development. Second Symposium on France-Taiwan Frontiers of Science Tentative Program.

Misra H, Fridovich I. 1972. The role of superoxide anion in the autooxidation of epinephrine and a simple assay for Superoxide Dismutase. J. Biol. Chem. 247, 3170.

Miyazawa M, Shindo M, Shimada S. 2002. Metabolism of $(+)$ - and (-)-limonenes to respective carveols and perillyl alcohols by CYP2C9 and CYP2C19 in human liver microsomes. Drug Metab. Dispos. 30, 602-607. http://dx.doi.org/ 10.1124/dmd.30.5.602.

Murali R, Karthikeyan A, Saravanan R. 2013. Protective effects of D-Limonene on lipid peroxidation and antioxidant enzymes in streptozotocin-induced diabetic rats. Basic Clin. Pharmacol. Toxicol. 112, 175-181. http://dx.doi.org/10.1111/ bcpt.12010.

Murray RK, Granner DK, Mayes PA, Rodwell VW. 2003. Harper's Illustrated Biochemistry 26th edn. McGraw-Hill.

Nigam S, Schewe T. 2000. Phospholipase $\mathrm{A}_{2}$ s and lipid peroxidation. Biochim. Biophys. Acta 1488, 167-181. http://dx.doi. org/10.1016/S1388-1981(00)00119-0.

Onyema OO, Farombi EO, Emerole GO, Ukoha AI, Onyeze GO. 2005. Effect of Vitamin E on Monosodium Glutamate induced hepatoxicity and oxidative stress in rats. Ind. $J$. Bioc. Biophys. 43, 20-24.

Pandya JD, Dave KR, Katyare SS. 2004. Effect of long-term aluminum feeding on lipid/phospholipid profiles of rat brain myelin. Lipid Health Dis. 3, 13. http://dx.doi.org/ 10.1186/1476-511X-3-13.

Qiao Y, Xie BJ, Zhang Y, ZhangY, Fan G, Yao XL, Pan SY. 2008. Characterization of Aroma Active Compounds in Fruit Juice and Peel Oil of Jinchen Sweet Orange Fruit (Citrus sinensis (L.) Osbeck) by GC-MS and GC-O. Molecules, 1333-1344. http://dx.doi.org/10.3390/molecules13061333.

Roth GS, Joseph JA, Mason RP. 1995. Membrane alterations as causes of impaired signal transduction in Alzheimer's disease and aging. Trends Neurosci Sci. 18, 203-206. http:// dx.doi.org/10.1016/0166-2236(95)93902-A.

Schafer FQ, Buettner GR. 2001. Redox environment of the cell as viewed through the redox state of the glutathione disulfide/ glutathione couple. Free RadicBiol Med. 30, 1191-1212. http://dx.doi.org/10.1016/S0891-5849(01)00480-4.

Wurtman RJ. 1985. Alzheimer's disease. Sci Am. 252, 62-66. http://dx.doi.org/10.1038/scientificamerican0185-62. 